\title{
KEBIJAKAN ASIMILASI TERHADAP NARAPIDANA DIMASA PANDEMI COVID-19
}

\author{
${ }^{1}$ Dinni Rachmawati Putri, ${ }^{2}$ Johari, ${ }^{3}$ Husni \\ Co. Author Email : johari@unimal.ac.id \\ ${ }^{1}$ Mahasiswa Fakultas Hukum Universitas Malikussaleh \\ ${ }^{2}$ Fakultas Hukum Universitas Malikussaleh
}

\begin{abstract}
The government responded to the conditions of the COVID-19 pandemic in Indonesia by releasing prisoners through an assimilation program. The condition of prisons in Indonesia which lacks capacity causes jostling of each other and there is no distance between prisoners so that social distancing cannot be carried out for the sake of preventing and overcoming COVID-19. This study discusses the assimaltion policy of prisoners during the COVID-19 pandemic. The purpose of this research is to discuss the policy of assimilation of prisoners before and during the COVID-19 pandemic as well as the assimilation policy of prisoners during the COVID-19 pandemic is in accordance with the objectives of prisons, namely after prisoners has served his sentence, the prisoner can live a better life in society and not repeat his crime again. The research method used in this research is juridical normative, which is a form of research that places law as a normative system. The norm system in question is regarding the principles, norms, laws and regulations, and doctrine (teachings) regarding the assimilation policy during the COVID-19 pandemic. Based on the results of the study, it was found that the regulation of the Minister of Law and Human Rights regarding the Assimilation Policy for prisoners was in effect before the COVID-19 pandemic. The Minister of Law and Human Rights issued the Assimilation Policy during the COVID-19 pandemic on the basis of government concerns about the spread of COVID-19 in prisons. Release of Prisoners is only focused on preventing COVID-19, but does not pay attention to aspects of justice and deterrent effects as the goal of correctional facilities. So that it will cause new problems.
\end{abstract}

Keywords : Assimilation Policy, Prisoners, COVID-19 


\section{PENDAHULUAN}

Salah satu upaya pemerintah dalam menghadapi pandemi ini adalah dengan dikeluarkannya Peraturan Menteri Hukum dan HAM Nomor 10 Tahun 2020 tentang Syarat Pemberian Asimilasi terhadap narapidana dengan tujuan untuk pencegahan dan penanggulangan penyebaran COVID-19. Akantetapi, pemberian asimilasi ditengah pandemi justru berdampak buruk bagi masyarakat. Pemerintah Indonesia menggunakan wewenangnya untuk mengeluarkan kebijakan asimilasi mengenai upaya untuk menahan laju penyebaran COVID-19 di Indoonesia melalui Kementerian Hukum dan Hak Asasi Manusia. Kebijakan tersebut didasari atas kekhawatiran pemerintah akan penyebaran COVID-19 di dalam lapas. Kurangnya kapasitas dalam lembaga pemasyarakatan mengakibatkan protokol kesehatan salah satunya jaga jarak atau social distancing tidak dapat diterapkan.

Masalah yang selalu timbul di dalam lembaga pemasyarakatan selaku lembaga untuk melaksanakan pembinaan bagi narapidana salah satunya adalah meningkatnya permasalahan kekurangan kapasitas. Data yang diambil dari bulan Juni 2020 Jumlah Penghuni Lapas Sebanyak 230.310 orang yang terdiri dari Tahanan sebanyak 50.276 dan Narapidana 180.084 (Ditjenpas, 2020). Hal itu memperlihatkan lapas di Indonesia sedang mengalami kekurangan kapasitas sehingga mencapai angka 74 persen dalam skala nasional. Adapun 33 Kanwil yang ada di Indonesia kini, terdapat 10 Kanwil diantaranya yang tidak mengalami kekurangan kapasitas. Beberapa kanwil tersebut adalah Kanwil D.I Yogyakarta, Gorontalo, Maluku, Maluku Utara,Kanwil Nusa Tenggara Timur, Papua, Kanwil Papua Barat, Sulawesi Barat, Sulawesi Tenggara dan Sulawesi Utara.

Pemerintah juga sudah membuat beberapa kebijakan, yaitu seperti perbaikan bangunan atau rehabilitasi sampai pembuatan gedung baru guna menambah daya tampung. Kondisi tersebut adalah sebuah masalah yang sangat serius dan harus segera terselesaikan. Salah satu cara untuk mengintegrasikan narapidana ke dalam masyarakat adalah melalui asimilasi yang merupakan bagian dari rencana pembangunan lapas. Undang-Undang Nomor 12 Tahun 1995 tentang Pemasyarakatan telah mencantumkan pasal yang mengatur tentang hak-hak narapidana, yaitu Pasal 14 ayat (1), Pasal 22 ayat (1) dan Pasal 29 ayat (1) (Trisnawati, 2020).

Hak-hak narapidana dan anak telah diatur dan dijamin dalam pasal-pasal tersebut, sehingga mengharuskan mereka dianggap sebagai subjek yang memiliki status yang sama dengan manusia lain. Asimilasi juga termasuk kedalam bagian dari hak Warga Binaan Pemasyarakatan (WBP) dan diatur dalam Peraturan Pemerintah Nomor 32 Tahun 1999 Tentang Syarat dan Tata Cara Pelaksanaan Hak Warga Binaan Pemasyarakatan dan Peraturan Menteri Hukum dan Hak Asasi Manusia Republik Indonesia (HAM RI) Nomor 03 Tahun 2018 Tentang Syarat dan Tata Cara Pemberian Remisi, Asimilasi, Cuti mengunjungi Keluarga, Pembebasan Bersyarat, Cuti Menjelang Bebas dan Cuti Bersyarat.

Namun penerapan dari kebijakan asimilasi untuk melepaskan narapidana sebagai pencegahan dan penanggulangan penyebaran COVID-19 tersebut telah menimbulkan kekhawatiran masyarakat. Masyarakat dihadapkan dengan keadaan ancaman sosial dan keamanan. Adapun Kepolisian RI mencatat bahwa angka kriminalitas terus meningkat selama masa pandemi. Pusat Kriminal Nasional Polri mencatat sejak dari dikeluarkannya narapidana-narapidana dari lapas melalui kebijakan asimilasi, maka terjadi pula peningkatan angka kriminalitas yaitu sebesar 11,80 persen dimulai dari pekan ke-5 hingga ke-16 (Muhammad Hidayat, 2021). Fokus utama perhatian ditujukan ke wilayah pemukiman dengan kejahatan yang sering terjadi yaitu penyalahgunaan narkotika dan pencurian. Adapun untuk tindak pidana pencurian terjadi dikarenakan lemahnya perekonomian disaat pandemi COVID-19 dikarenakan berlakunya PSBB (Pembatasan Sosial Berskala Besar) yang menyebabkan melonjakkan kemiskinan dan pengangguran (Rasyid Ridho, 
2021). Adapun data dari Kepala Biro Penerangan Divisi Hubungan Masyarakat Kepolisian Republik Indonesia angka kriminalitas dimasa pandemi pada pekan ke-35 kembali meningkat mencapai 4,49 persen dari pekan sebelumnya. Pekan ke-34 pada Agustus 2020 terdapat 4.449 kasus, kemudian meningkat hingga menjadi 4.649 kasus. Adapun kasus tertinggi adalah penyalahgunaan narkotika sebanyak 666 kasus, pencurian dengan pemberatan 559 kasus, penggelapan 370 kasus, pencurian sepeda motor 171 kasus, pemerkosaan 54 kasus (Rasyid Ridho, 2021). Selain itu, kejahatan ditengah pandemi ini para pelakunya mayoritas adalah narapidana residivis kebijakan asimilasi yang dikeluarkan oleh pemerintah melalui Departemen Hukum HAM. Persoalannya ialah, pembebasan napi yang cukup besar ditengah lesunya ekonomi akibat pandemi COVID-19 dapat meningkatkan kejahatan di tengah masyarakat. Pelaksanaa asimilasi dimasa pandemi COVID-19 di Indonesia ini bisa dikatakan belum seluruhnya tepat, karena akan memunculkan kasus baru yang akan merusak tujuan sesungguhnya dari kebijakan itu sendiri.

\section{METODE PENELITIAN}

Metode penelitian merupakan cara melakukan sesuatu menggunakan pikiran yang seksama untuk mencapai tujuan dengan mencari, mencatat, dan merumuskan serta menganalisis hingga menyusun laporan (Chalik Narkubo, 2007). Maka penulis menggunakan penelitian sebagai berikut : Jenis penelitian ini menggunakan penelitian yuridis normatif. Penelitian ini mengarah pada norma hukum yang terdapat pada peraturan perundang-undangan maupun putusan pengadilan dan juga pada norma-norma yang hidup dan berkembang dalam masyarakat. Adapun dengan melihat kesamaan suatu aturan dengan aturan hukum lainnya secara hierarki (Zainuddin, 2014). Pendekatan penelitian yang digunakan dalam penelitian ini adalah pendekatan penelitian yuridis normatif.

Penelitian yang dikaji peneliti dalam penelitian ini merupakan penelitian yang bersifat deskriptif. Adapun bentuk dari penelitian ini adalah perspektif. Jenis sumber data yang dipakai dalam penelitian ini bersumber dari data sekunder yang diperoleh melalui penelitian kepustakaan (library research) terkait kebijakan asimilasi terhadap narapidana dimasa pandemi COVID-19.

Penelitian ini juga menggunakan data mengenai kebijakan asimilasi terhadap narapidana dimasa pandemi COVID-19 yang digunakan sebagai bahan hukum pendukung dalam penelitian. Bahan hukum sekunder yang digunakan dalam penelitian hukum ini terdiri dari beberapa literatur/buku, jurnal, artikel, makalah dan hasil penelitian terdahulu yang berkaitan dengan masalah penelitian. Bahan hukum tersier merupakan bahan yang memberikan petunjuk ataupun penjelasan terhadap bahan hukum primer dan sekunder. Dalam penelitian ini bahan hukum tersier yang digunakan meliputi Kamus Besar Bahasa Indonesia (KBBI), Kamus-Kamus Hukum, ensiklopedia, situs Internet Yang berkaitan dengan Kebijakan Asimilasi Terhadap Narapidana Dimasa Pandemi COVID-19 Di Indonesia.

\section{HASIL PENELITIAN DAN PEMBAHASAN}

\section{Kebijakan Asimilasi Sebelum Dan Saat Masa Pandemi COVID-19}

\section{1). Kebijakan Asimilasi Sebelum Masa Pandemi COVID-19}

Narapidana berhak mengikuti asimilasi apabila telah memenuhi persyaratan substantif dan administratif seperti yang terdapat di pasal 7 dan pasal 8 Keputusan Menteri Kehakiman Republik Indonesia Nomor M.01.PK.04.10 Tahun 1999 tentang asimilasi. Adapun beberapa persyaratan substantif yang wajib dipenuhi narapidana adalah :

a. Narapidana dan anak didik pemasyarakatan telah menunjukkan kesadaran dan penyesalan atas kesalahan yang menyebabkan dijatuhi pidana;

b. Telah menunjukkan perkembangan budi pekerti dan moral yang positif;

c. Telah berhasil mengikuti program kegiatan pembinaan dengan tekun dan bersemangat; 
d. Masyarakat juga telah menerima program kegiatan pembinaan narapidana yang bersangkutan;

e. Selama menjalankan pidananya, narapidana dan anak didik pemasyarakatan belum pernah mendapat hukuman disiplin sekurang-kurangnya nya dalam waktu 9 (sembilan) bulan terakhir;

f. Adapun untuk asimilasi, narapidana telah menjalani pidana, setengah dari masa pidana setelah dikurangi masa tahanan dan remisi, dan dihitung sejak putusan pengadilan telah memperoleh kekuatan hukum tetap.

Persyaratan administratif berupa:

a. Adanya salinan putusan pengadilanan (ekstrak vonis);

b. Adanya surat keterangan asli dari kejaksaan yang menyatakan bahwa narapidana yang bersangkutan tidak mempunyai perkara atau tersangkut dengan tindak pidana lainnya;

c. Laporan penelitian kemasyarakatan (litmas) dari BAPAS tentang pihak keluarga yang akan menerima narapidana, dan laporan tentang keadaan masyarakat sekitarnya dan pihak lain yang ada hubungannya dengan narapidana tersebut;

d. Adanya salinan daftar mengenai perubahan atau pengurangan masa pidana, seperti grasi, remisi dan dan lain-lain dari kepala Lapas;

e. Adanya surat pernyataan kesanggupan dari pihak yang akan menerima narapidana, seperti pihak keluarga, sekolah, instansi pemerintah atau swasta dengan diketahui oleh pemerintah daerah setempat serendah-rendahnya lurah atau kepala desa;

f. Adanya surat keterangan kesehatan dari psikolog atau dari dokter yang menyatakan bahwa narapidana sehat baik jasmani maupun jiwanya dan apabila di Lapas tidak ada psikolog dan dokter, maka surat keterangan dapat dinyatakan oleh dokter Puskesmas atau Rumah Sakit Umum;

g. Untuk narapidana asing diperlukan syarat tambahan yaitu surat keterangan sanggup menjamin dari kedutaan besar/konsulat negara asing orang yang bersangkutan dan surat rekomendasi dari kepala kantor imigrasi setempat.

Selain dari ketentuan di atas, diperlukan kesediaan dari orang atau badan atau lembaga yang memberikan jaminan tertulis di atas meterai. Asimilasi tidak diberikan bagi narapidana yang nyawanya terancam dan diduga melakukan tindak pidana lain, serta tidak dapat diberikan pada narapidana yang sedang menjalani hukuman seumur hidup. Dengan adanya peraturan perundangundangan di atas maka proses pemberian asimilasi narapidana telah mempunyai aturan hukum tetap dan asimilasi merupakan hak narapidana yang didapat dengan cara mengikuti semua prosedur dan persyaratan yang telah ditentukan.

\section{2). Kebijakan Asimilasi Dimasa Pandemi COVID-19}

a). Peraturan Mentri Hukum dan Hak Asasi Manusia Nomor 10 Tahun 2020

Peraturan Menteri Hukum dan Hak Asasi Manusia (Permenkumham) Nomor 10 Tahun 2020 tentang persyaratan asimilasi di keluarkan oleh pemerintah Indonesia dalam rangka pencegahan dan penanggulangan penyebaran COVID-19 yang telah menyebar ke seluruh Indonesia, yang diundangkan pada bulan Maret 2020.

Untuk narapidana yang akan mendapatkan pembebasan melalui asimilasi, harus memenuhi syarat menurut Pasal 2 ayat (2) sebagai berikut :

1) Menunjukkan kelakuan baik dengan dibuktikan tidak sedang menjalani hukuman disiplin dalam waktu 6 enam bulan terakhir,

2) Telah aktif mengikuti program pembinaan dengan baik, serta

3) Sudah menjalanai satu per dua masa pidana. 
Persyaratan untuk pemberian asimilasi narapidana dan anak harus melampirkan dokumen seperti melampirkan fotokopi kutipan putusan hakim dan berita acara pelaksanaan putusan pengadilan, bukti telah melunasi denda atau uang pengganti sesuai dengan putusan pengadilan atau melaksanakan putusan subsidaer pengganti denda yang dilakukan di rumah dengan pengawasan Kejaksaan dan Bapas, laporan perkembangan pembinaan yang ditandatangani oleh Kepala Lapas, surat pernyataan dari narapidana bahwa ia tidak akan melarikan diri dan melakukan perbuatan melawan hukum serta surat salinanan pernyataan tersebut, dan salinan perubahan dari kepala lapas.

Keberadaan Permenkumham Nomor 10 Tahun 2020 ini merupakan peraturan hukum khusus sehingga dapat mengesampingkan ketentuan dalam hukum umum di Undang-Undang Nomor 12 Tahun 1995 tentang Lembaga Pemasyarakatan. Atau berdasarkan Asas Lex Spesialis Derogat Legi Generali, yaitu asas preferensi dimana hukum khusus menyampingkan hukum umum (Bagir Manan, 2004). Hal tersebut, karena di dalam Permenkumham Nomor 10 Tahun 2020 ini tidak diatur mengenai pemberian asimilasi kepada narapidana korupsi. Mengingat bahwa tindakan korupsi adalah termasuk kejahatan luar biasa (extra-ordinary crime) sehingga dalam penanganannya juga membutuhkan langkah luar biasa pula (extra ordinary measure).

b) Peraturan Mentri Hukum Dan Hak Asasi Manusia Nomor 32 Tahun 2020

Kementerian Hukum dan Hak Asasi Manusia mengeluarkan Peraturan Menteri Hukum dan Hak Asasi Manusia (Permenkumham) Nomor 32 Tahun 2020 tentang Syarat dan Tata Cara Pemberian Asimilasi, Pembebasan Bersayarat, Cuti Menjelang Bebas, dan Cuti Bersyarat bagi narapidana dan anak dalam rangka pencegahan dan penanggulangan penyebaran COVID-19. Sebagai pengganti Permenkumham Nomor 10 Tahun 2020 tentang Syarat Pemberian Asimilasi dan Hak Integrasi. Hal tersebut adalah upaya lanjutan untuk mencegah dan menanggulangi penyebaran COVID-19 di Lembaga Pemasyarakatan (lapas), Lembaga Pembinaan Khusus Anak (LPKA), dan Rumah Tahanan Negara (Rutan), melalui pemberian Asimilasi dan Integrasi.

Adapun dikeluarkannya Permenkumham Nomor 32 Tahun 2020 ini dengan alasan melihat beberapa peristiwa yang terjadi setelah adanya pengeluaran narapidana dan anak di tengah pandemi COVID-19 (Ditjenpas, 2021). Maka perlu dilakukan penyempurnaan. Beberapa hal diantaranya mengenai syarat dan tata cara pemberian hak terhadap Warga Negara Asing, dan penerbitan Surat Keputusan secara online, yang akan terakomodir dalam Sistem Database Pemasyarakatan. Selain itu asimilasi juga tidak dapat diberikan bagi narapidana dan yang telah melakukan tindak pidana pembunuhan yang terdapat dalam pasal 339 dan pasal 340 KUHP, pencurian dengan kekerasan dalam pasal 365 KUHP, kesusilaan dalam pasal 285 sampai dengan pasal $290 \mathrm{KUHP}$, dan juga kesusilaan terhadap anak sebagai korban yang terdapat di dalam pasal 81 dan pasal 82 UndangUndang Nomor 35 Tahun 2014 mengenai Perubahan atas Undang-Undang Nomor 23 Tahun 2002 Tentang Perlindungan Anak.

Saat dilakukan pengeluaran terhadap narapidana, maka narapidana tersebut diharapkan tidak melakukan pengulangan pelanggaran yang akan mengakibatkan keresahan di tengah masyarakat. Ada beberapa poin dalam penyempurnaan Permenkumham Nomor 32 Tahun 2020, yang diantaranya adalah penambahan subtansi, perubahan subtansi, dan penghapusan substansi. Beberapa point tersebut antara lain :

a) Pertama, perubahan judul dengan menjabarkan integrasi menjadi pembebasan Bersyarat, cuti menjelang bebas, dan cuti Bersyarat. Hal itu akan menyempurnakan penjelasan kepada masyarakat dan para pejabat yang menggunakan peraturan menteri mengenai pemberian hak integrasi yang meliputi pembebasan bersyarat dan cuti bersayarat karena hak integrasi agar lebih jelas.

b) Kedua, substansi pemberian asimilasi bagi narapidana warga negara asing. Untuk poin ini, ditujukan agar dapat mengakomodir tuntutan dari masyarakat rumah agar terhindar dari 
pelanggaran terhadap asas non diskriminatif dan mekanisme penunjukan tempat asimilasi bagi warga negara asing

c) Ketiga, Penambahan pada klausul pengecualian syarat terhadap pidana singkat. Adapun poin ini akan mengakomodir pidana dibawah 6 bulan bagi narapidana dan dibawah 3 bulan bagi anak.

d) Keemapat, terdapat perubahan dan penambahan syarat pada asimilasi. Poin ini memberikan kejelasan mengenai syarat tambahan bagi narapidana/anak yang akan mendapatkan program yaitu mewajibkan adanya penelitian kemasyarakatan ( litmas).

e) Kelima, penambahan alternatif tindak pidana. Pada poin ini, sebagai alternatif perumusan substansi yang mengakomodir pelaku tindak pidana pencurian pembunuhan dan asusila

f) Keenam, alternatif tindak pidana yang tidak diberikan asimilasi. Poin ini menjelaskan bahwa asimilasi tidak dapat diberikan terhadap warga binaan pemasyarakatan yang mengulangi tindak pidana dan tindak pidana yang sangat menarik perhatian masyarakat.

Diluar dari poin-poin yang telah dijelaskan tersebut, perubahan juga ada pada penambahan mekanisme pembatalan, penambahan syarat bagi warga negara asing, penambahan pencabutan asimilasi, menghilangkan syarat yang tidak dapat diukur, penambahan verifikasi oleh kantor wilayah, perubahan mekanisme cetak SK, dan masa berlaku Permenkumham.

Keseluruhan dari perubahan yang telah dirumuskan di dalam Permenkumham Nomor 32 Tahun 2020 memiliki tujuan untuk penyempurnaan implementasi program Asimilasi dan integrasi terkait pencegahan dan penyebaran COVID-19 yang telah berjalan selama hampir 1 tahun (Ditjenpas, 2021). Dengan demikian, maka diharapkan dengan adanya penyempurnaan aturan mengenai syarat pemberian asimilasi dan hak integrasi bagi narapidana dalam rangka pencegahan dan penanggulangan penyebaran COVID-19, maka program Asimilasi dan Integrasi yang telah diberikan kepada WBP lebih tepat sasaran dan dapat meminimalisirkan seluruh kekurangan yang telah terjadi sebelumnya.

\section{Kebijakan Asimilasi Dimasa Pandemi COVID-19 dan Tujuan Lembaga Pemasyarakatan}

\section{1). Problematika Lembaga Pemasyarakatan Indonesia}

Untuk memahami Permenkumham Nomor 10 Tahun 2020 tentang Syarat Pemberian Asimilasi, maka analisa secara tekstual maupun kontekstual sangat diperlukan, hal ini dapat dimulai dengan membaca ratio legis berbagai ketentuan Permenkumham tersebut. Lahirnya Permenkumham tersebut, memiliki tali temalinya dengan problematika Lembaga Pemasyarakatan yang klasik namun tidak kunjung terselesaikan $(C)$, yaitu kapasitas Lapas yang tidak mencukupi daya tampung (over capacity). Hal ini tergambar dari 525 Lapas dan rutan di Indonesia yang lazimnya hanya memiliki daya tampung maksimal 132.107 jiwa, justru dihuni oleh 270.231 jiwa (Ditjenpas, 2021).

Penghuni lapas yang melebihi kapasitas bukan saja tidak manusiawi, akan tetapi juga melanggar kebijakan menjaga jarak (social distancing). Hal tersebut yang menjadi faktor utama dikeluarkannya kebijakan darurat terkait asimilasi narapidana dimasa pandemi COVID-19. Institute for Criminal Justice Reform (ICJR) menyatakan ada tujuh lembaga pemasyarakatan (lapas) yang sudah terpapar COVID-19. Terdapat 120 warga binaan pemasyarakatan (WBP) dan 18 petugas lapas yang terinfeksi COVID-19. Setelah mengamati kondisi di Lapas negara yang setidaknya telah tercatat terdapat 91 tahanan yang terkonfirmasi virus COVID-19. Dari berbagai praktik tersebut, pemerintah Indonesia setidaknya menggunakan skema asimilasi, guna mengikuti praktik pembebasan narapidana dan anak binaan yang saat ini berada dalam berbagai Lapas di Indonesia. 


\section{2). Dampak Dari Pemberian Asimilasi Dimasa Pandemi COVID-19}

Tidak dapat dipungkiri dengan kondisi pandemi, para narapidana yang baru dibebaskan juga mengalami kesulitan dalam ekonomi sehingga memicu untuk kembali berbuat kriminal, belum lagi anggapan buruk masyarakat pada narapidana sehingga menjadikannya sulit untuk diterima kembali di masyarakat. Selain memberikan dampak positif berupa telah memberikan ruang berjarak di dalam lapas bagi narapidana serta narapidana bisa menerapkan protokol kesehatan berupa social distancing, kebijakan asimilasi terhadap narapidana ini juga telah memberikan dampak negatif dimasa pandemi COVID-19. Pertama, dimasa pandemi COVID-19 ini, para eks narapidana akan dihadapkan dalam keadaan yang sangat susah untuk mendapatkan pekerjaan. Hal tersebut bukanlah tanpa sebab, setelah melihat situasi COVID-19 ini yang telah menyebabkan banyaknya perusahaan yang mengalami "gulung tikar", menghentikan operasinya, merumahkan para karyawan, juga melakukan pemutusan hubungan kerja, dan lainnya. Kedua, sangat maraknya praktik jual beli tiket pembebasan narapidana di lapas. Ketiga, adanya aksi kriminalitas mulai bermunculan.

Ada dua asumsi penting untuk menjelaskan peningkatan kriminalitas ini. Pertama, kebijakan pencegahan dan mitigasi COVID-19 yang banyak bertumpu pada pembatasan kegiatan di luar rumah telah berdampak cukup hebat pada stabilitas ekonomi mayoritas masyarakat, khususnya masyarakat kelas bawah. Akibat kebijakan tersebut, tidak sedikit di antara mereka kemudian melakukan tindakan kriminal sebagai jalan pintas. Kedua, sebagai bagian dari kebijakan pencegahan dan mitigasi COVID-19, pemerintah juga telah membebaskan lebih dari 30.000 narapidana.

Para narapidana yang telah diberikan asimilasi tersebut bukan hanya belum memiliki pekerjaan dan penghasilan tetap ketika keluar dari penjara, tapi pada saat yang bersamaan, mereka juga langsung dihadapkan pada kenyataan sulitnya mencari kerja dan penghasilan karena kebijakan mitigasi COVID-19. Mereka kemudian mengambil jalan pintas dengan melakukan kriminalitas kembali untuk mencari makan. Adapun fakta bahwa narapidana kembali berulah tersebut dapat menjadi tanda bahwa dalam proses melakukan penilaian perilaku terhadap narapidana sebelum mereka dibebaskan kembali dan dibiarkan berbaur ke masyarakat sangatlah kurang efektif. Untuk itu, ketika pemerintah juga tidak dapat menjamin bahwa narapidana yang mendapatkan asimilasi dimasa pandemi tidak akan melakukan tindakan kriminalnya lagi, maka hal lain yang dapat dijamin oleh pemerintah adalah dalam pengawasan dan tindakan dari petugas yang senantiasa berjaga setelah para narapidana ini dibaurkan ke dalam masyarakat. Adapun Kepala Badan Pemeliharaan Keamanan Polri menyatakan bahwa kebanyakan naiknya kasus tersebut disebabkan oleh faktor ekonomi. Saat para narapidana yang telah mendapatkan asimilasi ditengah pandemi kembali ke keluarganya, maka tidak sedikit anggota keluarga yang baru saja di PHK sehingga akan menjadi himpitan ekonomi turunnya penghasilan, dan diwaktu yang bersamaan kebutuhan pun semakin meningkat yang akhirnya mendorong narapidana asimilasi tersebut mengambil jalan pintas yaitu dengan melakukan tindak kriminal.

\section{KESIMPULAN}

Berdasarkan hasil dari pembahan tersebut diatas, maka diketahui bahwa dasar hukum berlakunya kebijakan asimilasi narapidana sebelum pandemi COVID-19 adalah Undang-Undang Nomor 12 Tahun 1995 tentang Pemasyarakatan. Adapun kebijakan asimilasi terhadap narapidana dimasa pandemi COVID-19 lahir atas dasar kekhawatiran pemerintah akan kondisi pandemi COVID-19 yang telah menyebar luas di Indonesia, tidak terkecuali di dalam lapas. Keadaan lembaga pemasyarakatan di Indonesia yang kekurangan kapasitas menyebabkan terjadinya saling berdesakan dan tidak ada jarak diantara narapidana sehingga tidak dapat diterapkannya Social Distancing demi pencegahan dan penanggulangan COVID-19. Kebijakan tersebut dituangkan 
dalam Peraturan Menteri Hukum dan HAM Nomor 10 Tahun 2020 dan Peraturan Menteri Hukum dan HAM Nomor 32 Tahun 2020. Semua narapidana yang mendapatkan asimilasi dimasa pandemi dan keluar dari Lembaga Pemasyarakatan diharapkan untuk dapat merefleksikan dirinya dan berhenti melakukan kembali kejahatan. Adapun terhadap narapidana yang mendapatkan asimilasi dimasa pandemi kemudian kembali melakukan kejahatan menjadi bukti bahwa kebijakan asimilasi terhadap narapidana dimasa pandemi COVID-19 kurang efektif, dan tidak sesuai dengan tujuan sebenarnya dari lembaga pemasyarakatan sehingga menimbulkan masalah baru.

\section{DAFTAR PUSTAKA}

Bagir Manan, 2004, Hukum Positif Indonesia, Yogyakarta, Perpustakaan Pusat UIN Walisongo Chalik Narbuko dan Abu Achmadi, 2007 Metode Penelitian, Bumi Aksara, Jakarta, Bumi Aksara

Ditjen Pas, Sistem Database Pemasyarakatan, http://smslap.ditjenpas.go.id/public/grl/current/monthly. Diakses Tanggal 21 September 2020.

Nian Ati Trisnawati, 2020, Pemberian Asimilasi dan Integrasi Terhadap Narapadina dan Anak Dalam Rangka Pencegahan Dan Penanggulangan Penyebaran COVID-19, Jurnal Ilmiah Ilmu Hukum, Volume 26 Nomor 14

https://riset.unisma.ac.id/index.php/jdh/article/view/7259 Di Akses Tanggal 5 September 2020

Muhammad Hidayat, 2020, Kriminalitas meningkat selama pandemi,

https://koran.tempo.co/read/metro/457569/kriminalitas-meningkat-selama-masa-pandem Diakses tanggal 10 Februari 2021.

Republik Indonesia, Peraturan Menteri Hukum dan Hak Asasi Manusia Nomor 03 Tahun 2018 tentang Syarat dan Tata Cara Pemberian Remisi, Asimilasi, Cuti Mengunjungi Keluarga, Cuti Menjelang Bebas dan Cuti Bersyarat

Republik Indonesia, Keputusan Menteri Kehakiman Nomor M.01.PK.04.10 Tahun 1999 tentang asimilasi, pembebasan bersyarat dan cuti menjelang bebas

Republik Indonesia, Keputusan Menteri Hukum dan Hak Asasi Manusia Nomor M.HH19.PK.01.04.04 Tahun 2020 tentang Pengeluaran dan Pembebasan Narapidana dan Anak Melalui Asimilasi dan Integrasi Dalam Rangka Pencegahan dan Penanggulangan Penyebaran COVID-19

Rasyid Ridho, Pandemi COVID-19, Angka Kriminalitas Meningkat, https://amp/s/amp.kompas.com/regional/read/pandemi-COVID-19-angkakriminalitasmeningkat/2020/12/24.Diakses Tanggal 10 Februari 2021

Zainuddin Ali, 2014, Metode Penelitian Hukum, Jakarta, Sinar Grafika 